\title{
PROGRAM STRATEGIS DALAM MENGATASI KENDALA KELEMBAGAAN PENGELOLAAN EKOWISATA BAHARI DI RAJA AMPAT (Studi Kasus: Kampung Wisata Distrik Meos Mansar) Strategic Programs for Overcoming Institutional Obstacles of Marine Ecotourism Management in Raja Ampat (Case Study: Tourism Villages in Meos Mansar District)
}

\author{
*Nur Aini', Arif Satria', Ekawati Sri Wahyuni', dan Dietrich G. Bengen ${ }^{2}$ \\ ${ }^{1}$ Departemen Sains Komunikasi dan Pengembangan Masyarakat, \\ Fakultas Ekologi Manusia, IPB University \\ JI. Raya Dramaga, Kampus IPB Dramaga Bogor, Jawa Barat, Indonesia \\ ${ }^{2}$ Departemen IImu Teknologi Kelautan, Fakultas Perikanan dan IImu Kelautan, IPB University \\ JI. Raya Dramaga, Kampus IPB Dramaga Bogor, Jawa Barat, Indonesia \\ Diterima tanggal: 12 Januari 2020; Diterima setelah perbaikan: 5 Juli 2021; \\ Disetujui terbit: 13 Desember 2021
}

\begin{abstract}
ABSTRAK
Raja Ampat merupakan kawasan potensial ekowisata bahari di jantung segitiga terumbu karang dunia dan untuk mengembangkan potensi tersebut, pemerintah setempat menetapkan pembentukan kampung-kampung wisata di sejumlah lokasi. Dalam perkembangannya, kelembagaan pengelolaan kampung-kampung wisata ini tidak terlepas dari tantangan untuk mengakomodasikan berbagai kepentingan dan pengaruh para pemangku kepentingan. Penelitian ini bertujuan untuk: (i) mengkaji kepentingan dan pengaruh pemangku kepentingan yang ada, (ii) mengidentifikasi kendala kelembagaannya, dan (iii) merumuskan program strategis yang dibutuhkan untuk meningkatkan kinerja pengelolaan kampung-kampung wisata tersebut. Lokasi penelitian mencakup Kampung Arborek, Yenbuba dan Sawinggrai Distrik Meos Mansar Kabupaten Raja Ampat. Penelitian dilaksanakan pada bulan September hingga Oktober 2020, dengan dua pendekatan analisis yaitu Interpretative Structural Modeling (ISM) dan deskriptif kualitatif. Hasil penelitian menunjukkan bahwa pemerintah, Dewan Adat Suku Maya, dan Conservation International Indonesia berada pada posisi key player, dengan kepentingan dan pengaruh yang tinggi terhadap pengelolaan ekowisata bahari di kampungkampung wisata. Kelompok masyarakat dan swasta berada pada posisi subyek dengan kepentingan yang tinggi terhadap sumber daya alam tinggi, namun memiiki pengaruh yang rendah dalam pengambilan keputusan. Hasil penelitian juga menunjukkan adanya kendala kelembagaan dalam pengelolaan kampung wisata, yaitu konflik pemanfaatan ruang dalam sistem pengelolaan tarif Kartu Jasa Lingkungan (KJL). Penelitian ini merekomendasikan sebuah intervensi kebijakan berupa program strategis yang terdiri dari beberapa level dan diprioritaskan pada: (i) pengembangan pengelolaan kolaboratif antar stakeholders, (ii) pemberdayaan masyarakat, (iii) peningkatan efektivitas konservasi, dan (iv) pendistribusian akses yang adil kepada masyarakat.
\end{abstract}

Kata Kunci: ekowisata bahari; kampung wisata; kelembagaan; kendala kelembagaan; pengembangan ekowisata; program strategis; Raja Ampat

\section{ABSTRACT}

Raja Ampat is a potential marine tourism area located in the coral triangle. In 2009, the Raja Ampat Regency Government designated several villages as tourism villages to encourage economic growth in the community in the tourism sector. The management of marine ecotourism in Raja Ampat Tourism Village is inseparable from several institutional obstacles. Every stakeholder involved in management has an interest and influence. This study aims to examine stakeholder mapping, institutional constraints, and strategic programs needed for marine ecotourism management in tourist villages. The research location is in Arborek Village, Yenbuba and Sawinggrai, Meos Mansar District, Raja Ampat Regency. The analysis technique used is Interpretative Structural Modeling (ISM) and qualitative descriptive analysis. The results showed that the government, the Maya tribe Adat Council, and Conservation International Indonesia are the key players who had a high interest and influence on marine ecotourism management. Community and private groups are in subjects position who had a high interest in natural resources, but their influence in decision-making is low. The management of marine ecotourism in the tourist village 
of Raja Ampat has several institutional obstacles. The main obstacle is conflict over space utilization in the environmental service card tariff management system. To overcome the obstacles, it is necessary to implement strategic programs effectively. This study suggests a strategic program consisting of several levels. The strategic programs that are prioritized are the development of collaborative management among stakeholders, community empowerment, increasing conservation effectiveness, and distributing access to the community.

Keywords: ecotourism development; institutional; institutional constraints; marine ecotourism; tourism village; strategy program; Raja Ampat

\section{PENDAHULUAN}

Raja Ampat memiliki keanekaragaman hayati berupa 456 jenis karang keras, 699 jenis moluska dan 828 jenis ikan karang (Rudyanto, Rumetna, Setyawan, \& Prabowo, 2015). Fakta seperti ini dimaknai oleh pemerintah setempat sebagai potensi dan peluang besar untuk pengembangan ekonomi melalui pembangunan kawasan wisata bahari (Bappeda, 2010). Sejalan dengan hal tersebut, Pemerintah Kabupaten Raja Ampat menetapkan visi jangka menengah tahun 2016-2021 yang memberikan perhatian penuh pada pengembangan potensi maritimnya, yaitu "Gerakan Membangun Pariwisata dan Ekonomi Masyarakat untuk Mewujudkan Raja Ampat sebagai Kabupaten Bahari yang Sejahtera" (Peraturan Daerah Kabupaten Raja Ampat No. 2 Tahun 2016).

Di sisi lain, untuk pengembangan potensi ekonomi bebasis wisata bahari, terdapat ramburambu yang yang secara tegas harus dipatuhi oleh pelaksana pembangunan di kabupaten tersebut. Rambu-rambu tersebut adalah Keputusan Menteri (Kepmen) Kelautan RI No. 36/KEPMENKP/2014 tentang penetapan Perairan Raja Ampat sebagai Kawasan Konservasi Perairan Daerah (KKPD). Kepmen ini menunjukkan adanya amanat pemerintah pusat kepada daerah untuk menjaga keberlanjutan dari ekosistem perairan daerah tersebut (Hukom, Yulianda, Bengen, \& Kamal, 2019). Dengan demikian, pemerintah setempat memandang bahwa konsep wisata yang dikembangkan di wilayahnya adalah ekowisata. Dalam ekowisata, terkandung sejumlah pengertian penting, diantaranya: (i) kegiatan menikmati alam dan budaya, ii) berkontribusi pada kesejahteraan masyarakat, (iii) tidak bersifat konsumtif, (iv) fokus pada pengalaman dan pendidikan tentang alam, dan (v) bersifat melestarikan lingkungan dan (Wood, 2002; Damanik \& Weber, 2006). Ini berarti bahwa ekowisata menjadikan tujuan konservasi berjalan bersamaan dengan pembangunan ketahanan sosial-ekologis
(Honrado et al., 2017). Pembangunan ketahanan sosial-ekologis dicapai melalui terbukanya peluang kerja bagimasyarakat dan masyarakat berpartisipasi dalam menjaga dan melestarikan alam.

Dalam upaya pengembangan ekowisata bahari yang digagas oleh Pemerintah Kabupaten Raja Ampat, salah satu tantangan signifikan yang dihadapi oleh perencana, pengambil keputusan dan para pelaksana adalah beragamnya pengaruh dan kepentingan masing-masing pemegang peran dalam pengelolaan ekowisata bahari. Terkait ini, penting untuk mempertimbangkan laporan Reed et al. (2009), yang mengemukakan pentingnya pemetaan pemangku kepentingan. Pemetaan pemangku kepentingan mengandung arti mendefinisikan aspek fenomena sosial dan alam yang dipengaruhi oleh keputusan atau tindakan, mengetahui relasi antar pihak dalam kemampuan mempengaruhi atau dipengaruhi, dan melihat posisi pemangku kepentingan dalam keterlibatan pengambilan keputusan. Lebih lanjut, dalam Hiwasaki (2007) dikatakan bahwa interaksi antara pemangku kepentingan dapat mengarah pada hubungan kekuasaan dalam mengakses manfaat. Distribusi manfaat yang tidak proporsional diantara pemangku kepentingan dapat menyebabkan kegagalan pengelolaan sumber daya (He et al., 2008).

Setelah memahami peta pemangku kepentingan, pertanyaan menantang berikutnya adalah bagaimana mengakomodasikan segenap kepentingan dan mengoptimalkan peran dan pengaruh masing-masing pihak dalam kelembagaan yang efektif untuk menjalankan berbagai tindakan dan mencapai tujuan. Kelembagaan (atau institusi) adalah aturanaturan, norma dan strategi yang mengarahkan tindakan kolektif, untuk menentukan siapa yang memenuhi syarat dalam membuat keputusan pada arena tertentu, dan menentukan bentuk-bentuk tindakan yang diizinkan dan yang dibatasi (Ostrom, 1990; Satria, 2009; Fidelman et al., 2012). 
Kelembagaan memegang peranan penting dalam pembangunan berkelanjutan; sementara itu, kelembagaan yang kuat dan berkualitas akan mampu mempengaruhi perilaku masyarakat, dan mendorong untuk melaksanakan kegiatan/tindakan secara efektif (Brinkerhoff \& Goldsmith, 1992).

Salah satu bentuk tindakan yang direncakan dalam kerangka pengembangan ekowisata bahari Raja Ampat adalah pemberlakuan tarif masuk (Perbup No. 63/2007, yang kemudian disempurnakan menjadi tarif layanan pemeliharaan jasa lingkungan (Perbup No. 18/2014). Tarif masuk kawasan wisata dikelola oleh Dinas Pariwisata dan Kebudayaan sedangkan tarif layanan pemeliharaan jasa lingkungan dikelola oleh Unit Pelaksana Teknis Badan Layanan Umum Daerah (UPT BLUD). Pendapatan daerah dari tarif layanan pemeliharaan jasa lingkungan atau Kartu Jasa Lingkungan (KJL) mengalami peningkatan setiap tahunnya, Rp. 1,5 Miliyar pada tahun 2007 menjadi 14,4 Miliyar pada tahun 2016 (Dinas Kebudayaan dan Pariwisata Kabupaten Raja Ampat, 2016). Diharapkan bahwa tren positif ini terus berlanjut, dan wisata di wilayah tersebut pada waktunya dapat berkontribusi secara signifikan terhadap peningkatan kualitas hidup masyarakat.

Isu terkait KJL sejauh ini masih menjadi permasalahan pelik, yang merujuk pada pendapat Brinkerhoff \& Goldsmith (1992) dapat diatasi dengan adanya kelembagaan yang kuat. Pemangku kepentingan dalam pengelolaan kampung-kampung wisata bahari belum dengan pengaruh dan kepentingannya masing-masing sulit untuk melakukan langkah terpadu, termasuk terkait pengelolaan sistem tarif KJL. Kendala kelembagaan pengelolaan $\mathrm{KJL}$ juga memiliki hubungan kontekstual dengan kendala kelembagaan lainnya yang dihadapi dalam pengelolaan ekowisata bahari di Kampung Wisata Raja Ampat. Ini berarti bahwa penguatan kelembagaan akan berdampak multi aspek pada kinerja pengelolaan kawasan di Raja Ampat, termasuk ekowisata dan komponenkomponen di dalamnya. Karenanya, keterpaduan dalam kelembagaan pengelolaan yang menuntut konsistensi internal antara kebijakan dan aksi sebagaimana dimaksudkan oleh Thia-Eng (2006), menjadi sangat penting.

Berdasarkan hal tersebut, muncul pertanyaan penelitian yang sangat relevan, bagaimana struktur dari kendala kelembagaan ada pada pengelolaan Kampung Wisata Raja Ampat dan bagaimana program strategis yang diperlukan untuk mengatasi kendala tersebut?. Untuk itu, penelitian yang dilaporkan dalam makalah ini bertujuan: (i) mengkaji pepentingan dan pengaruh masingmasing pemangku kepentingan yang ada; (ii) mengidentifikasi kendala kelembagaannya, dan (iii) merumuskan program strategis yang dibutuhkan untuk meningkatkan kinerja pengelolaan kampungkampung wisata.

Data penelitian meliputi data primer dan data sekunder. Data primer diperoleh melalui wawancara mendalam, wawancara pakar model struktural kelembagaan, Focus Group Discussion (FGD) dan observasi partisipatif. Hasil dari pengamatan, wawancara dan FGD dituangkan dalam catatan harian dengan bentuk uraian rinci dan kutipan langsung. Data sekunder diperoleh melalui berbagai literatur seperti jurnal, buku, Badan Pusat Statistik (BPS), undang-undang, peraturan daerah, profil kampung wisata, Rencana Induk Pengembangan Pariwisata Daerah (RIPPDA) Kabupaten Raja Ampat, laporan Dinas Pariwisata dan Kebudayaan (DPK), hasil kajian The Nature Conservancy maupun Conservation Indonesia dan literatur lain yang mendukung kebutuhan data penelitian.

Sumber data primer adalah informan sebagai orang yang menceritakan tentang kondisi dan lingkungannya. Pada penelitian ini terdapat 25 informan yang meliputi pihak Badan Perencana dan Pembangunan Daerah (Bappeda), Dinas Pariwisata dan Kebudayaan (DPK), Unit Pelaksana Teknis Badan Layanan Umum (UPT BLUD), The Nature Conservancy (TNC), Conservation International (Cl) Indonesia, kepala kampung, pengurus asosiasi homestay Raja Ampat, masyarakat pelaku wisata, masyarakat non pelaku wisata, dan pihak swasta, termasuk asosiasi homestay, pemilik resort. Pemilihan informan dilakukan dengan teknik snowballing, yaitu dengan mencari informan kunci kemudian berlanjut kepada informan lainnya hingga informasi dan data jenuh (data atau informasi sudah terkonfirmasi sama).

Pertanyaan penelitian terkait kepentingan dan pengaruh pemangku kepentingan dianalisis dengan pendekatan deskriptif kualitatif. Sementara itu, pertanyaan penelitian mengenai kendala kelembagaan dan program strategis dianalisis menggunakan teknik analisis ISM dan dilengkapi dengan analisis deskriptif kualitatif. Pendekatan Interpretative Structural Modelling (ISM) (Saxena, \& Vrat, 1992; Mohammed, Shankar, \& Banwet, 2008), yang umum digunakan sebagai 
alat perencanaan strategis, dapat diterapkan untuk menjawab pertanyaan tersebut. ISM dalam penelitian ini digunakan untuk mengidentifikasi hubungan kontekstual antar sub-elemen dalam elemen kendala kelembagaan dan elemen program strategis dengan melibatkan diskusi bersama para pakar atau informan yang memahami konteks permasalahan di lokasi penelitian. ISM terdiri dari dua bagian yaitu klasifikasi sub elemen dan penyusunan hirarki yang memberikan nilai manfaat dalam membentuk suatu sistem pengambilan keputusan. Penyusunan hirarki membentuk model struktural dan menunjukkan posisi key player (faktor penentu) dari kendala yang dihadapi dan program strategis. Dengan demikian, metode ISM dapat mengidentifikasi hubungan kontekstual dan menentukan kendala utama yang perlu diselesaikan serta program strategis yang perlu diprioritaskan.

Sementara itu, mengacu pada (Creswell, 2014), analisis deskriptif kualitatif dilakukan mengikuti tiga tahap. Ketiga tahan tersebut adalah reduksi data, penyajian data dan verifikasi data. Reduksi data dilakukan dengan pemilihan, penyederhanaan, abstraksi, hingga transformasi data hasil wawancara mendalam, observasi, dan studi dokumen. Tujuan dari reduksi data ini adalah untuk mempertajam, menggolongkan, mengarahkan, dan membuang data yang tidak perlu. Penyajian data dalam bentuk narasi, gambar, dan tabel, selanjutnya data diverifikasi. Verifikasi data sebagai penarikan kesimpulan dari hasil yang telah diolah pada tahap reduksi. Verifikasi dilakukan dengan mendiskusikan hasil olahan data kepada informan, dan para pakar.

Penelitian dilakukan bulan September 2020 dan Oktober 2020 di 3 (tiga) kampung di Distrik Meos Mansar, Kabupaten Raja Ampat, Provinsi Papua Barat, yaitu Kampung Arborek, Sawinggrai dan Yenbuba. Kampung-kampung yang berada di kawasan Selat Dampier ini merupakan bagian zona semi intensif, yang diperbolehkan untuk menerima kunjungan wisatawan dalam skala lebih kecil dengan aktivitas wisata yang terbatas dan bersifat spesifik. Aktivitas tersebut misalnya adalah pengamatan satwa liar, jelajah hutan, diving, snorkeling, dan kayaking, yang difasilitasi oleh bangunan resort maksimum bertingkat dua dengan jumlah kamar terbatas dan homestay (Bappeda, 2010). Saat ini, homestay berjumlah 40, tersebar di Arborek(12), Yenbuba (Kri Island) (20), dan Sawinggrai (8).

\section{PEMETAAN PEMANGKU KEPENTINGAN (STAKEHOLDER)}

Para pemangku kepentingan yang terlibat dalam pengelolaan ekowisata dikelompokkan menjadi kelompok pemerintah, swasta, masyarakat dan lembaga swadaya masyarakat. Satria (2002) menyatakan bahwa aktor-aktor yang terlibat dalam proses pengelolaan sumber daya adalah pemerintah, masyarakat atau kerja sama di antara keduanya (co-management). Posisi stakeholders diidentifikasi berdasarkan kepentingan dan pengaruh masing-masing stakeholder. Hero (2012), Muttaqin (2012), \& Nurfatriani, Darusman, Nurrochmat, \& Yustika (2015), menyatakan bahwa tingkat pengaruh stakeholder diidentifikasi melalui kemampuan memiliki kewenangan dalam membuat kebijakan, memfasilitasi implementasi kebijakan dan memengaruhi pihak lain dalam membuat kebijakan. Reed et al. (2009) membangun matrik kepentingan pengaruh (interestinfluence matrix) ke dalam empat kategori yaitu: key players, context setters, subjects, dan crowd (Bryson, 2004; Reed et al., 2009). Berikut matriks kepentingan dan pengaruh pemangku kepentingan dalam pengelolaan ekowisata bahari di kampung wisata Distrik Meos Mansar Kabupaten Raja Ampat.

Pada Gambar 1, terlihat bahwa pemerintah pusat, pemerintah provinsi, pemerintah kabupaten, Disparbud, UPT BLUD, Dishub, Diskop dan UKM, satpol air, Dewan Adat Suku Maya, dan Cl Indonesia termasuk kategori key players yang memiliki kepentingan dan pengaruh tinggi. Pemerintah kabupaten memiliki kepentingan tinggi terkait peningkatan pendapatan daerah melalui sektor pariwisata, peningkatan kesejahteraan masyarakat melalui pengembangan pariwisata berkelanjutan, pelaksanaan perencanaan dan pembangunan sesuai visi misi pemerintah daerah, dan pelestarian lingkungan melalui kegiatan konservasi.

Pemerintah kabupaten berkoordinasi dengan SKPD, seperti Disparbud, UPT BLUD, Dishub, Diskop dan UKM, dan satpol air untuk menjalankan fungsi pelaksana. Pemerintah provinsi memiliki pengaruh tinggi terhadap pengaturan, penyediaan dan peruntukan berbagai infrastruktur kebutuhan pariwisata berkelanjutan. Selain dalam di dalam rentang koordinasi pemerintah provinsi terdapat Dewan Adat Suku Maya yang memiliki hak ulayat dalam mengatur pengelolaan dan perlindungan sumber daya alam di kawasan Raja Ampat sesuai dengan ketetapan hukum. Dalam upaya 


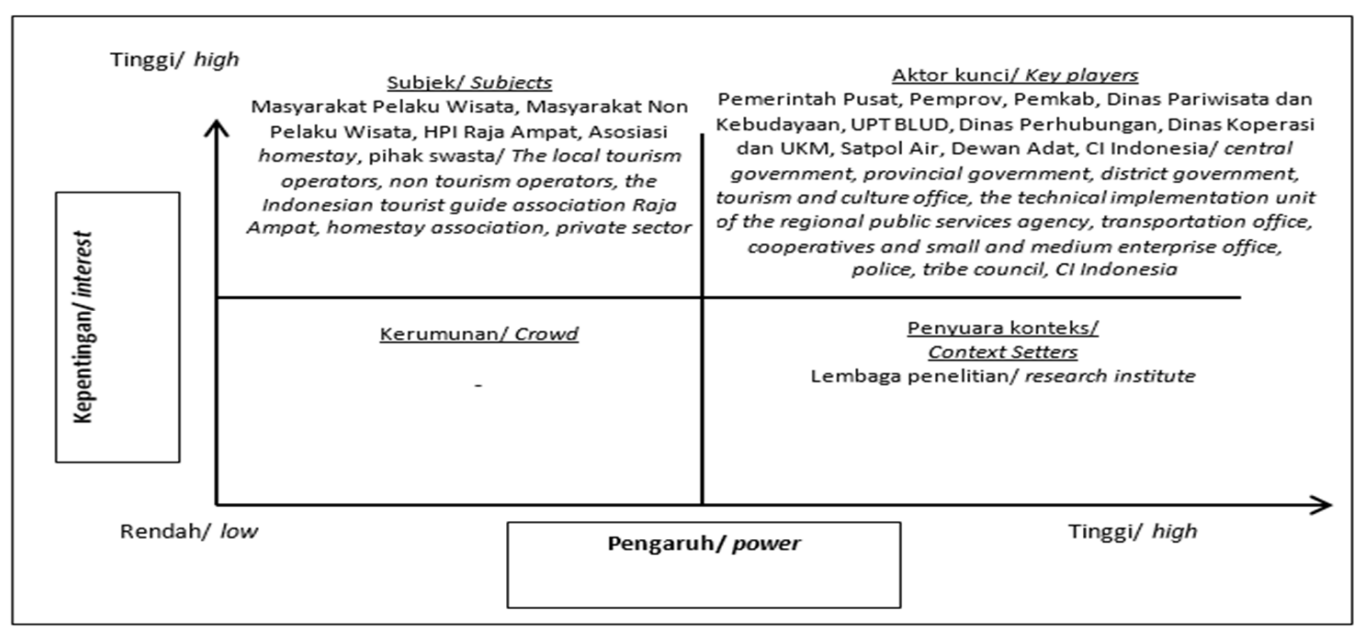

Gambar 1. Matriks Kepentingan dan Pengaruh Pemangku Kepentingan dalam Pengelolaan Ekowisata Bahari Kampung Wisata Distrik Meos Mansar Kabupaten Raja Ampat.

Figure 1. Interest and Power Stakeholder Matrix on Marine Ecotourism Management in Tourism Villages Meos Mansar District, Raja Ampat Rregency.

Sumber: data primer (2020)/ Source: primary data (2020).

perlindungan sumber daya alam, Conservation International $(\mathrm{Cl})$ Indonesia berperan sebagai Lembaga Swadaya Masyarakat (LSM) yang aktif terlibat dalam program konservasi di bagian utara Raja Ampat.

Berdasarkan matriks kepentingan dan pengaruh stakeholders, kelompok masyarakat seperti masyarakat pelaku wisata, masyarakat non pelaku wisata, HPI Raja Ampat, asosiasi homestay Raja Ampat, dan pihak swasta masuk ke dalam kategori subjects, yang memiliki kepentingan tinggi namun pengaruhnya rendah. Kelompokmasyarakattersebutmemilikikepentingan dan ketergantungan tinggi terhadap sumber daya alam sebagai sumber mata pencaharian. Tingginya kepentingan masyarakat tidak didukung oleh tingginya pengaruh masyarakat terhadap penetapan kebijakan pengelolaan ekowisata bahari di kampung wisata Raja Ampat. Rendahnya pengaruh yang dimiliki masyarakat menyebabkan tuntutan masyarakat mengenai pendistribusian alokasi dana dari pendapatan tarif Kartu Jasa Lingkungan (KJL) belum diakomodir secara baik. Berdasarkan peraturan bupati, terdapat alokasi dana kesejahteraan masyarakat dari tarif KJL setiap tahunnya. Akan tetapi, masyarakat baru menerima satu kali pendistribusian dana kesejahteraan pada tahun 2017.

Di sekitar Kampung Wisata Distrik Meos Mansar Kabupaten Raja Ampat terdapat pihak swasta yang meliputi resort, liveaboard dan agen perjalanan. Pihak swasta masuk dalam kategori subjects yang memiliki kepentingan tinggi dalam perolehan ekonomi dan pengaruh yang rendah terhadap penetapan kebijakan pengelolaan sumber daya alam. Beberapa resort yang berada di sekitar kawasan kampung wisata Arborek, Yenbuba dan Sawinggrai terdiri dari Kri Eco Resort-Papua Diving, Raja Ampat Dive Lodge, dan Papua Explorers Resort.

Lembaga yang masuk dalam kategori context setter terdiri dari lembaga penelitian atau akademisi seperti Universitas Cendrawasih dan Lembaga IImu Pengetahuan Indonesia (LIPI). Context setters adalah pemangku kepentingan yang memiliki pengaruh yang tinggi, tetapi memiliki kepentingan yang rendah terhadap sumber daya alam. Pihak akademisi memberikan gagasan dalam mendukung kemajuan pengelolaan sumber daya alam. Lembaga peneliti bekerja sama dengan Conservation International (CI) Indonesia dalam kajian A Marine Rapid Assemessment (MRAP) untuk pemetaan potensi bahari Raja Ampat. Dari hasil penelitian tersebut menjadi dasar pembentukan penetapan Kawasan Konservasi Laut Daerah (KKLD) Kabupaten Raja Ampat.

\section{KENDALA KELEMBAGAAN PENGELOLAAN EKOWISATA BAHARI}

Terdapat sebelas sub-elemen kendala kelembagaan yang dihadapi dalam pengelolaan ekowisata bahari di kampung wisata Distrik Meos Mansar Kabupaten Raja Ampat. Berdasarkan hasil analisis jawaban dari informan, maka dibuat matriks jawaban (VAXO) mengenai kendala kelembagaan yang disajikan pada Tabel 1. 
Tabel 1. Matriks Elemen Kendala Kelembagaan dalam Pengelolaan Ekowisata Bahari di Kampung Wisata Distrik Meos Mansar Kabupaten Raja Ampat.

Table 1. The Matrix of Elements of Institutional Constraints in Marine Ecotourism Management in the Tourism Village, Meos Mansar District, Raja Ampat Regency.

\begin{tabular}{|c|c|c|c|c|c|c|c|c|c|c|c|}
\hline Elemen $\mathrm{j} /$ element $\mathrm{j}$ & K1 & K2 & K3 & K4 & K5 & K6 & K7 & K8 & K9 & K10 & K11 \\
\hline \multicolumn{12}{|l|}{ Elemen i/ element $i$} \\
\hline [K1] Konflik pemanfaatan ruang/ Space utilization conflicts & & $\mathrm{V}$ & $\mathrm{O}$ & $\mathrm{X}$ & $\mathrm{X}$ & $\mathrm{O}$ & V & $\mathrm{V}$ & $\mathrm{V}$ & $\mathrm{V}$ & V \\
\hline [K2] Kurangnya dukungan modal/ Lack of capital support & & & V & $\mathrm{X}$ & A & $\mathrm{O}$ & V & V & $\mathrm{X}$ & $\mathrm{V}$ & $\mathrm{V}$ \\
\hline $\begin{array}{l}\text { [K3] Terbatasnya kualitas SDM/ Limited quality of human } \\
\text { resources }\end{array}$ & & & & A & O & 0 & O & 0 & A & $X$ & 0 \\
\hline $\begin{array}{l}\text { [K4] Koordinasi antar lembaga belum efektif/ Coordination } \\
\text { between institutional has not been effective }\end{array}$ & & & & & $x$ & 0 & V & $\mathrm{V}$ & 0 & 0 & 0 \\
\hline $\begin{array}{l}\text { [K5] Penegakan hukum belum efektif/ Law enforcement } \\
\text { has not been effective }\end{array}$ & & & & & & 0 & V & $X$ & 0 & 0 & 0 \\
\hline $\begin{array}{l}\text { [K6] Rendahnya kewenangan masyarakat/ low community } \\
\text { authority }\end{array}$ & & & & & & & 0 & $A$ & $A$ & 0 & 0 \\
\hline $\begin{array}{l}\text { [K7] Upaya konservasi belum optimal/ Conservation efforts } \\
\text { are not optimal }\end{array}$ & & & & & & & & $X$ & $A$ & 0 & 0 \\
\hline $\begin{array}{l}\text { [K8] Belum optimalnya pelaksanaan rencana program } \\
\text { pembangunan/ The implementation of the development } \\
\text { programs plan are not optimal }\end{array}$ & & & & & & & & & V & V & 0 \\
\hline $\begin{array}{l}\text { [K9] Terbatasnya akses yang dimiliki masyarakat/ Limited } \\
\text { community access }\end{array}$ & & & & & & & & & & V & V \\
\hline $\begin{array}{l}\text { [K10] Belum optimalnya upaya pemasaran/ } \\
\text { Not optimal marketing efforts }\end{array}$ & & & & & & & & & & & 0 \\
\hline $\begin{array}{l}\text { [K11] Terbatasnya dukungan sarana dan prasarana/ } \\
\text { Limited support for facilities and infrastructure }\end{array}$ & & & & & & & & & & & \\
\hline
\end{tabular}

Sumber: data primer (2020)/ Source: primary data (2020).

Berdasarkan matriks driver power dan dependent, klasifikasi dari elemen kendala kelembagaan yang dihadapi dalam pengelolaan ekowisata bahari di kampung wisata Distrik Meos Mansar Kabupaten Raja Ampat menempati empat kuadran sebagaimana disajikan pada Gambar 2.
Berdasarkan Gambar 2, klasifikasi sub-elemen kendala kelembagaan dikelompokkan ke dalam empat kuadran yaitu autonomous, dependent, linkage dan independent. Kendala kelembagaan yang termasuk ke dalam kuadran autonomous adalah rendahnya

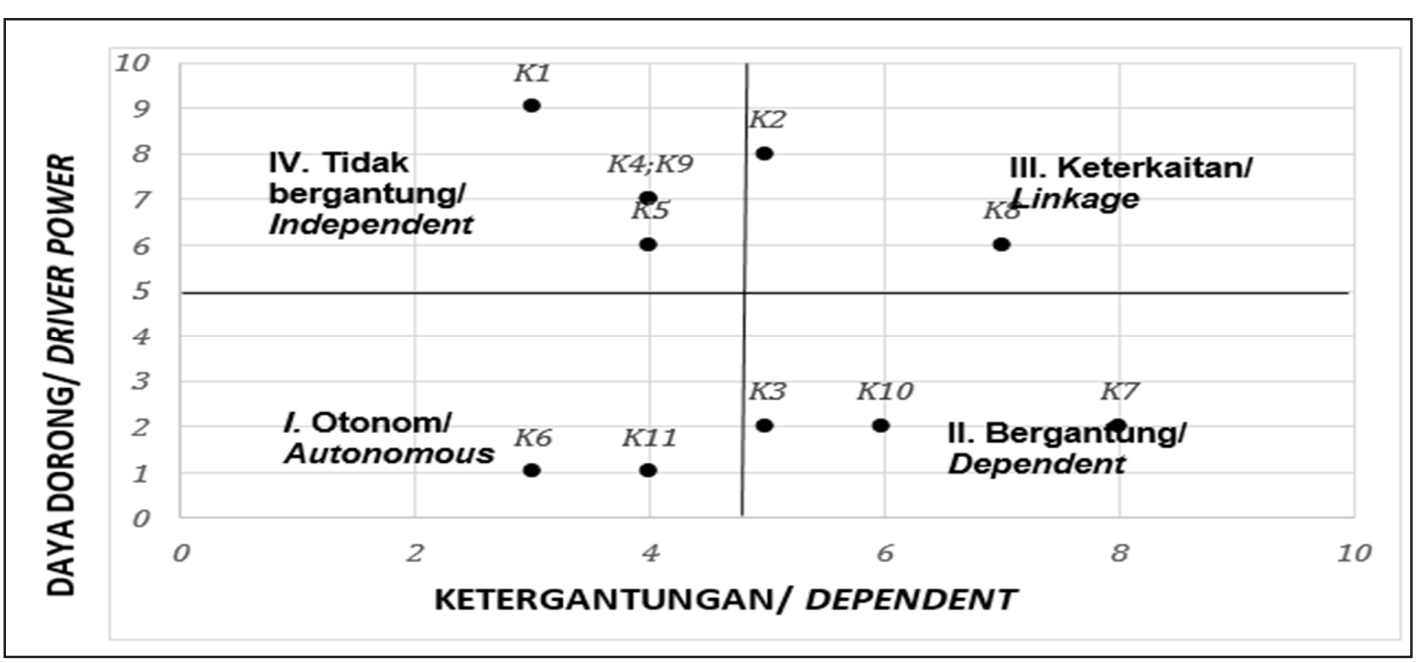

Gambar 2. Matriks Daya Dorong dan Ketergantungan pada Elemen Kendala Kelembagaan (K) Pengelolaan Ekowisata Bahari di Kampung Wisata Distrik Meos Mansar Kabupaten Raja Ampat.

Figure 2. Matrix of Driving Force and Dependenncy Level on Institutional Constraints Elements in Marine Ecotourism Management in the Tourism Village, Meos Mansar District, Raja Ampat Regency.

Sumber: data primer (2020)/ Source: primary data (2020). 
kewenangan masyarakat dan terbatasnya sarana dan prasarana penunjang wisata. Kedua kendala tersebut memiliki daya dorong (driving power) yang rendah dan tingkat ketergantungan (dependency level) yang rendah, sehingga tidak tergantung dengan sub-elemen lain dalam mempengaruhi sistem pengembangan dan pengelolaan ekowisata bahari di kampung wisata Distrik Meos Mansar Kabupaten Raja Ampat.

Sub-elemen kendala yang menempati kuadran dependent adalah terbatasnya kualitas sumber daya manusia, belum optimalnya upaya pemasaran dan upaya konservasi belum optimal. Hal ini menunjukkan bahwa ketiga sub-elemen tersebut memiliki tingkat ketergantungan yang tinggi dengan sub-elemen kendala yang lain dan tidak memiliki kekuatan penggerak yang tinggi terhadap sub-elemen kendala yang lain. Sub-elemen kendala kelembagaan pada kuadran dependent merupakan kendala kelembagaan yang timbul akibat adanya pengaruh sub-elemen kendala kelembagaan pada kuadran linkage dan independent. Guna mengatasi kendala yang berada pada kuadran dependent diawali dengan mengatasi kendala pada kuadran linkage dan independent terlebih dahulu.

Pada kuadran linkage terdapat sub-elemen kendala kurangnya modal dan belum optimalnya pelaksanaan rencana program pembangunan. Kedua sub-elemen tersebut memiliki daya penggerak tinggi dan tingkat ketergantungannya tinggi terhadap sub-elemen kendala kelembagaan pada kuadran lain. Walaupun kedua sub-elemen tersebut menjadi penyebab/penggerak kendala lain, namun penyelesaian kendala pada

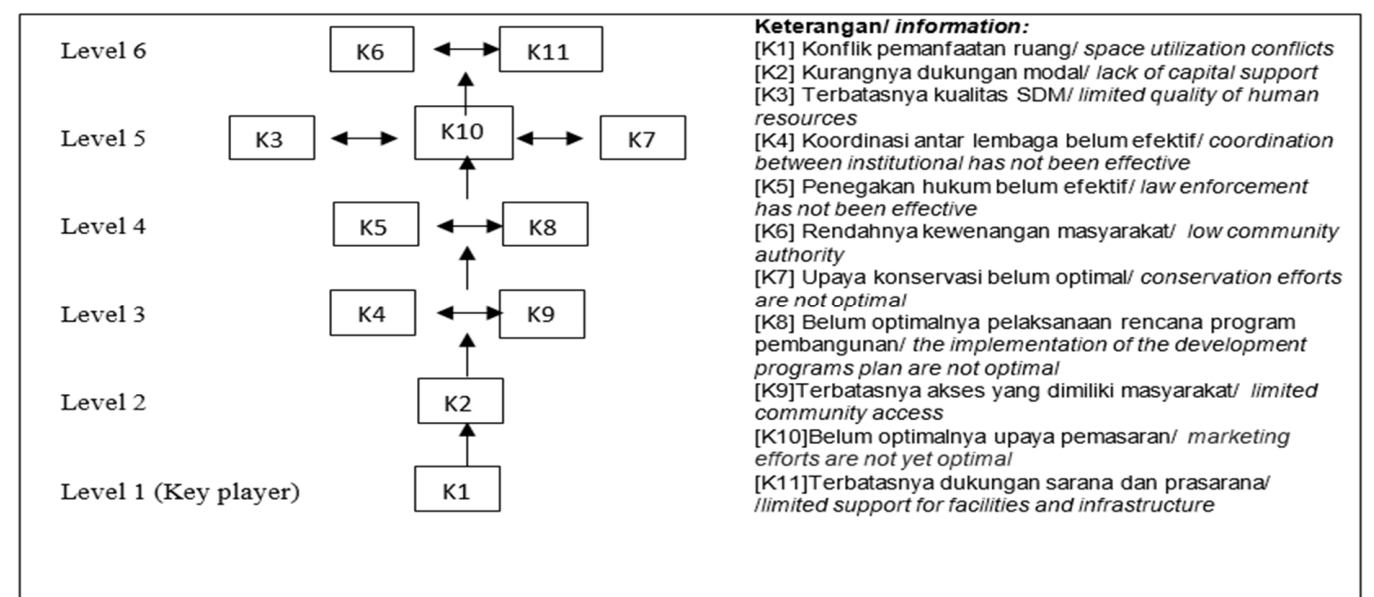

Gambar 3. Struktural Kendala Kelembagaan (K) Pengelolaan Ekowisata Bahari di Kampung Wisata Distrik Meos Mansar Kabupaten Raja Ampat.

Figure 3. Structural of Institutional Constraints Management of Marine Ecotourism in Tourism Village, Meos Mansar District, Raja Ampat Regency.

Sumber: data primer (2020)/ Source: primary data (2020) kuadran linkage ini bergantung pada penyelesaian kendala lain terutama kendala pada kuadran independent.

Sub-elemen kendala yang berada pada kuadran independent menjadi kendala utama yang penyelesaiannya perlu diprioritaskan karena menjadi elemen yang memiliki kekuatan penggerak yang besar dan tingkat ketergantungan yang rendah terhadap sub-elemen kendala lainnya. Sub-elemen kendala pada kuadaran independent meliputi konflik pemanfaatan ruang, koordinasi antar lembaga belum efektif, terbatasnya akses yang dimiliki masyarakat terhadap sumber daya wisata dan penegakan hukum belum efektif. Apabila keempat sub-elemen tersebut belum teratasi dengan baik, maka akan mempengaruhi munculnya kendala lain dan mempengaruhi pada ketidakefektifan pengembangan dan pengelolaan ekowisata bahari di kampung wisata Raja Ampat.

Hasil analisis menggunakan model ISM menghasilkan struktur hirarki sub-elemen kendala kelembagaan yang dihadapi dalam pengelolaan ekowisata bahari di kampung wisata Distrik Meos Mansar Kabupaten Raja Ampat seperti yang disajikan pada Gambar 3.

Hasil analisis struktural kendala ekowisata bahari di kampung wisata menunjukkan bahwa terdapat 6 level. Level pertama terdiri dari sub-elemen kendala konflik pemanfaatan ruang (K1). Konflik pemanfaatan ruang terjadi pada sistem pengelolaan dan pemanfaatan tarif Kartu Jasa Lingkungan (KJL) yang dinilai belum efektif pengelolaan dan distribusi manfaatnya.

tion conflicts resources

gan masyarakat/ low community

K7] Upaya konservasi belum optimal/ conservation efforts are not optima programs plan are not optimal

community access

efforts are not yet optima

sarana dan prasarana

imited support for facilities and infrastructure kelembagaan yang dihadapi dalam pengelolaan 
Pada awalnya berdasarkan Peraturan Bupati (Perbup) No. 63,64,65 tahun 2007, tarif masuk wisata Raja Ampat dikelola oleh Dinas Pariwisata dan Kebudayaan Raja Ampat. Akan tetapi mulai 1 Januari 2015, sistem tarif masuk wisata Raja Ampat berubah nama menjadi tarif layanan pemeliharaan jasa lingkungan berdasarkan Perbup No. 18 Tahun 2014 yang pengelolaannya dialihkan ke Unit Pelaksana Teknis Badan Layanan Umum Daerah (UPT BLUD). Berdasarkan hasil wawancara dengan informan dari Conservation Internasional Indonesia menyatakan bahwa:

\section{“ Sekarang ini yang masih belum beres adalah terkait tarif KJL. Rencananya mau dibuat pengelolaan satu pintu yang diinisiasi oleh pemda Raja Ampat. Pengelolaan satu pintu ini merupakan gabungan dari BKSDA, UPT BLUD, Dispar, KKPN oleh kementerian kelautan, dan pihak terkait lainnya yang masing-masing punya peran dan kepentingan didalamnya. Mereka harus bersama sepakati model pengelolaan satu pintu itu seperti apa, namun hingga saat ini yang belum ada titik temu. Diskusi bersama juga terbatas karena adanya pandemik ini"}

Kendala kelembagaan pada Level 2 meliputi kurangnya dukungan modal (K2) yang dimiliki masyarakatkhususnyauntukmembangun homestay dan memiliki kapal sebagai moda transportasi wisatawan. Modal ekonomi yang dibutuhkan untuk membangun sebuah homestay dan membeli kapal dengan 1 mesin tempel 15 Paardenkracht (PK) adalah masing-masing minimal 20 juta. Meskipun ada bantuan berupa dana pinjaman dari bank, bantuan kapal dari dana desa dan bantuan fasilitas homestay dari Dinas Kebudayaan dan Pariwisata Kabupaten Raja Ampat, bantuan tersebut masih terbatas dan belum merata diterima oleh masyarakat. Berdasarkan Peraturan Bupati Raja Ampat Nomor 18 Tahun 2014, terdapat tarif layanan pemeliharaan jasa lingkungan yang dibebankan kepada wisawatan. Dari pendapatan tarif tersebut, ada alokasi dana untuk kesejahteraan masyarakat yang telah ditetapkan dalam aturan. Alokasi dana tersebut penting untuk didistribusikan secara adil dan transparansi.

Pada Level 3, kendala kelembagaan yang dihadapi adalah koordinasi antar lembaga yang belum efektif (K4) dan terbatasnya akses yang dimiliki masyarakat (K9). Koordinasi antar lembaga yang belum efektif dipicu oleh adanya konflik pemanfaatan ruang. Pada kendala terbatasnya akses yang dimiliki masyarakat terhadap sumberdaya wisata ditandai dengan rendahnya akses melalui penguasaan teknologi, modal, kewenangan, dan relasi sosial yang dimiliki masyarakat. Pada Level 4, kendala kelembagaan yang dihadapi adalah penegakan hukum yang belum efektif dan belum optimalnya pelaksanaan rencana program pembangunan. Pertama, penegakan hukum yang belum efektif (K5) adalah terkait pembuangan limbah rumah tangga ke laut, khususnya di kampung Sawinggrai. Kedua, penegakan hukum lepas jangkar bagi kapal-kapal yang berlabuh. Ketiga, penegakan hukum pada kegiatan wisata pemberian makan ikan (fish feeding). Telah terdapat aturan berupa pembatasan waktu pemberian dan jenis makan yang diberikan. Waktu pemberian makan ikan ditentukan hanya pada sore hari, agar ikan dapat mencari makanannya terlebih dahulu secara alami dan tidak berdampak pada rusaknya rantai makanan. Jenis makanan yang boleh diberikan hanya terbatas pada makanan alami. Akan tetapi aturan-aturan tersebut masih kerap dilanggar oleh wisatawan dan belum ada pengawasan yang ketat.

Kendala belum optimalnya pelaksanaan rencana program pembangunan (K8) meliputi terbatasnya pelatihan, belum adanya tata kelola wisata liveaboard (kapal layar), dan pemasaran yang belum optimal. Masyarakat cukup sering menghadiri pertemuan berupa sosialisasi terkait upaya konservasi, namun pelatihan keterampilan maupun pengetahuan tentang upaya pengembangan ekowisata belum dilakukan secara rutin dan merata di kampung wisata. Pelatihan yang sudah dilaksanakan hanya melibatkan perwakilan masyarakat dan belum melibatkan seluruh masyarakat pelaku wisata. Selain peningkatan pelatihan, perlu tata kelola wisata liveaboard yang mengatur kebijakan melibatkan pemandu lokal dalam mendampingi tamu liveaboard, mendorong kerja sama penyewaan alat snorkeling dan diving antar pihak liveaboard dan masyarakat. Dengan demikian, hadirnya liveaboard memberi dampak perekonomian masyarakat kampung wisata.

Pada Level 5 terdapat tiga kendala yaitu terbatasnya kualitas sumber daya manusia (K3), belum optimalnya upaya pemasaran (K10) dan upaya konservasi yang belum optimal (K7). Pertama, terbatasnya kualitas Sumber Daya Manusia (SDM) dipengaruhi oleh masih terbatasnya pelatihan pengembangan SDM yang 
dilakukan. Kedua, pemasaran yang dilakukan masyarakat lokal dinilai masih terbatas dan belum ada dukungan penuh dari pemerintah. Sebagian besar pelaku wisata bergantung pada pemasaran melalui website yang dikelola asosiasi homestay Raja Ampat melalui www. stayrajaampat.com. Ketika homestay tidak ada wisatawan, pemilik homestay harus tetap membayar agar iklan homestay mereka tetap ada di website. Hal tersebutlah yang memberatkan sebagian besar pemilik homestay.

Kendala kelembagaan pada Level 6 yaitu mencakup rendahnya kewenangan masyarakat (K6) dan terbatasnya dukungan sarana dan prasarana (K11). Masyarakat yang memiliki kewenangan dalam pengambilan keputusan didominasi oleh tokoh adat, tokoh agama, tokoh pemuda dan aparatur kampung. Triyanti \& Susilowati (2019) mengemukakan bahwa pendekatan partisipasif dapat dipergunakan untuk mendorong masyarakat sampai pada tahap bersedia terlibat dan bersedia mencoba lalu memelihara hasilnya. Maka perlunya keterlibatan atau partisipasi masyarakat dalam pengambilan keputusan, karena masyarakat sebagai aktor utama pengguna sumber daya alam.

Kendala kelembagaan selanjutnya adalah terbatasnya dukungan sarana dan prasarana.
Berdasarkan hasil wawancara dengan satu pemilik homestay mengemukakan "ada fasilitas yang biasa diminta oleh tamu homestay yaitu alat snorkling. Tapi fasilitas itu belum bisa kami penuhi karena kami belum punya fasilitas alat snorkling untuk tamu. Namun secara umum fasilitas homestay menurut kami sudah terpenuhi". Fasilitas secara umum yang telah dipenuhi oleh mayoritas homestay di kampung adalah fasilitas kamar berupa kasur, kelambu, bantal, lemari, meja, kursi, handuk, hammock, kamar mandi di dalam atau di luar, sedangkan fasilitas umum meliputi dermaga, tempat duduk pinggir pantai (para-para), listrik 12 jam (18.00-06.00 WIT), lampu jalan, dan menara telekomunikasi.

\section{PROGRAM STRATEGIS PENGELOLAAN EKOWISATA BAHARI}

Berdasarkan wawancara mendalam bersama informan kunci dan analisis Rencana Induk Pengembangan Pariwisata Daerah (RIPPARDA) Kabupaten Raja Ampat terdapat sepuluh sub-elemen program strategis yang dibutuhkan dalam pengelolaan ekowisata bahari di kampung wisata Distrik Meos Mansar Kabupaten Raja Ampat. Pada Tabel 2 disajikan jawaban dari para informan terkait hubungan antar sub elemen tersebut.

Tabel 2. Matriks Program Strategis Pengelolaan Ekowisata Bahari di Kampung Wisata Distrik Meos Mansar Kabupaten Raja Ampat.

Table 2. Matrix of Strategic Program for Marine Ecotourism Management in Tourism Village, Meos Mansar District, Raja Ampat Regency.

\begin{tabular}{|c|c|c|c|c|c|c|c|c|c|c|}
\hline Elemen j & P1 & P2 & P3 & P4 & P5 & P6 & P7 & P8 & P9 & P10 \\
\hline $\begin{array}{l}\text { [P1] Pendataan seluruh kondisi dan potensi kawasan/ Data collection on } \\
\text { all area conditions and potentials }\end{array}$ & & $\mathrm{O}$ & A & A & $\mathrm{X}$ & A & $\mathrm{X}$ & A & $A$ & A \\
\hline $\begin{array}{l}\text { [P2] Menyusun program perencanaan ekowisata yang berkelanjutan/ } \\
\text { Compiling a sustainable ecotourism planning program }\end{array}$ & & & $\mathrm{X}$ & $\mathrm{X}$ & $x$ & $x$ & $\mathrm{~V}$ & $x$ & $X$ & $x$ \\
\hline $\begin{array}{l}\text { [P3] Menguatkan kelembagaan tingkat lokal hingga tingkat kabupaten/ } \\
\text { Strengthen local level ecotourism institutions }\end{array}$ & & & & A & $\mathrm{X}$ & $X$ & $\mathrm{~V}$ & $x$ & $X$ & $x$ \\
\hline $\begin{array}{l}\text { [P4] Mengembangan pengelolaan kolaboratif antar stakeholders/ } \\
\text { Develop collaborative management among stakeholders }\end{array}$ & & & & & $\mathrm{X}$ & $\mathrm{X}$ & $\mathrm{X}$ & $x$ & $X$ & $\mathrm{X}$ \\
\hline $\begin{array}{l}\text { [P5] Program pengawasan dan evaluasi yang efektif/ An effective } \\
\text { monitoring and evaluation program }\end{array}$ & & & & & & A & $\mathrm{X}$ & $\mathrm{X}$ & $\mathrm{X}$ & $\mathrm{X}$ \\
\hline [P6] Pemberdayaan masyarakat/ Community empowerment & & & & & & & $\mathrm{V}$ & $\mathrm{X}$ & $\mathrm{X}$ & $\mathrm{X}$ \\
\hline $\begin{array}{l}\text { [P7] Peningkatan sarana dan prasarana/ improvement of facilities and } \\
\text { infrastructure }\end{array}$ & & & & & & & & $x$ & $A$ & $A$ \\
\hline [P8] Kejelasan batas wilayah/ Clarity of boundaries & & & & & & & & & A & A \\
\hline $\begin{array}{l}\text { [P9] Meningkatkan efektivitas konservasi/ Increase the efeectiveness of } \\
\text { conservation }\end{array}$ & & & & & & & & & & $\mathrm{X}$ \\
\hline $\begin{array}{l}\text { [P10] Pendistribusian akses yang adil kepada masyarakat/ Distribution } \\
\text { of fair access to the community }\end{array}$ & & & & & & & & & & \\
\hline
\end{tabular}

Sumber: data primer (2020)/ Source: primary data (2020). 


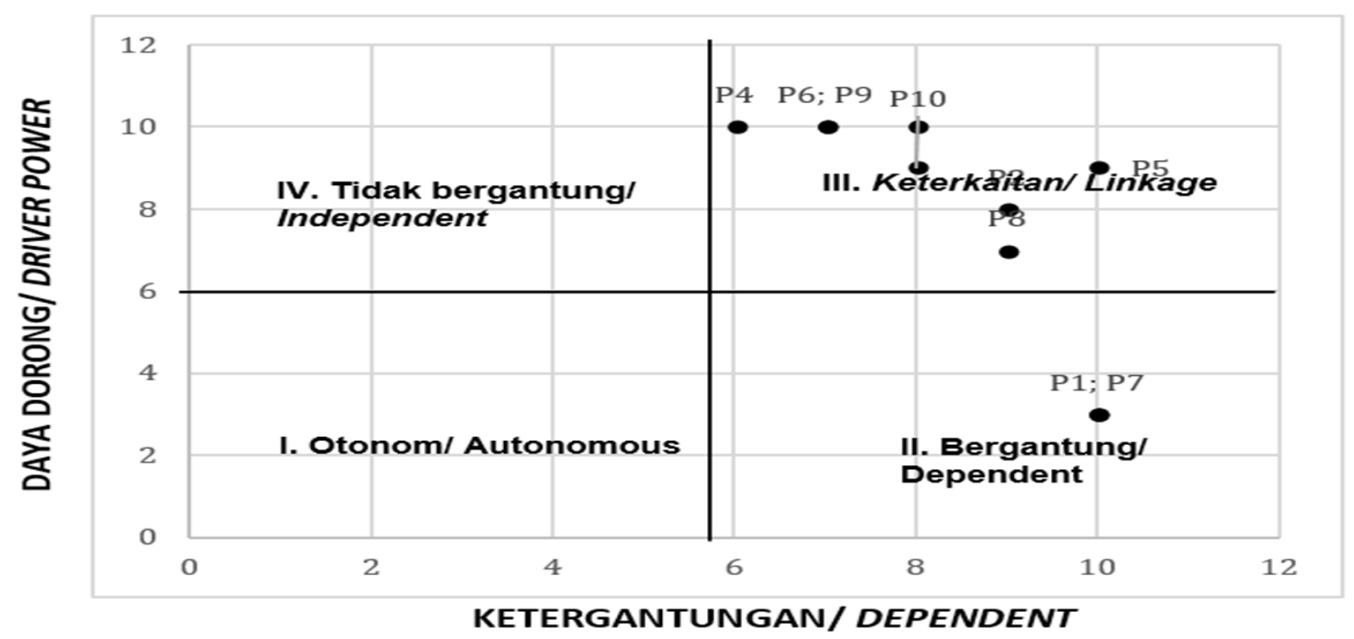

Gambar 4. Matriks Daya Dorong dan Ketergantungan Elemen Program Strategis (P) dalam Pengelolaan Ekowisata Bahari di Kampung Wisata Distrik Meos Mansar Kabupaten Raja Ampat.

Figure 4. Matrix of Driving Force and Dependency Level on of Strategy Program Elements in for Marine Ecotourism Management in the Tourism Village, Meos Mansar District, Raja Ampat Regency.

Sumber: data primer (2020)/ Source: primary data (2020)

Berdasarkan matriks driving force dan dependency level, klasifikasi dari elemen program strategis $(P)$ dalam pengelolaan ekowisata bahari di kampung wisata Distrik Meos Mansar Raja Ampat menempati empat kuadran sebagaimana disajikan pada Gambar 4.

Gambar 4 menunjukkan bahwa dua sub-elemen program strategis berupa pendataan seluruh kondisi dan potensi kawasan dan peningkatan fasilitas sarana dan prasarana berada pada kuadran dependent. Kedua sub-elemen program strategis pada kuadran dependent memiliki daya dorong rendah dan tingkat ketergantungan tinggi terhadap program strategis lainnya, sehingga kurang diprioritaskan menjadi program strategis dalam pengembangan dan pengelolaan ekowisata bahari di kampung wisata Distrik Meos Mansar Kabupaten Raja Ampat. Berbeda dengan delapan sub-elemen program strategis yang berada pada kuadran linkage. Sub-elemen program strategis yang berada pada kuadran linkage memiliki daya torong tinggi dan tingkat ketergantungannya terhadap program strategis lain juga tinggi. Sub elemen pada kuadran lingkage potensial diprioritaskan. Sub-elemen tersebut meliputi pengembangan pengelolaan kolaboratif antar stakeholders, pendataan seluruh kondisi dan potensi kawasan, pemberdayaan masyarakat, meningkatkan efektivitas konservasi, pendistribusian akses yang adil kepada masyarakat, menguatkan kelembagaan ekowisata tingkat lokal, program pengawasan dan evaluasi yang efektif, menyusun program perencanaan ekowisata yangberkelanjutan, dan kerja sama pendanaan lintas sektoral.

Berdasarkan hasil analisis dengan menggunakan ISM, diperoleh model struktural program strategis yang diharapkan dalam pengelolaan ekowisata bahari sebanyak lima level. Level pertama merupakan sektor kunci (key player) yang menjadi pendorong bagi program strategis pada level selanjutnya (level 2 sampai level 5), sehingga merupakan prioritas program strategis. Struktural program strategis yang diperlukan dalam pengelolaan ekowisata bahari di kampung wisata Distrik Meos Mansar Kabupaten Raja Ampat dapat disajikan pada Gambar 5.

Berdasarkan hasil analisis ISM terdapat 5 level struktural program strategis yang diperlukan dalam pengelolaan ekowisata bahari di kampung wisata Raja Ampat. Sub-elemen program strategis pada level 1 dapat menjadi pendorong elemen program strategis pada level selanjutnya. Sub-elemen program strategis pada Level 1 meliputi pengembangan pengelolaan kolaboratif antar stakeholders, pemberdayaan masyarakat, meningkatkan efektivitas konservasi dan pendistribusian akses yang adil kepada masyarakat. Dalam pengelolaan yang sinergis dan berkelanjutan, perlu menekankan kolaborasi antara pemangku kepentingan dengan membentuk aliansi (Yeboah-Assiamah, 2016; Kanyuuru et al., 2017). Brown (2018) menambahkan bahwa antar 


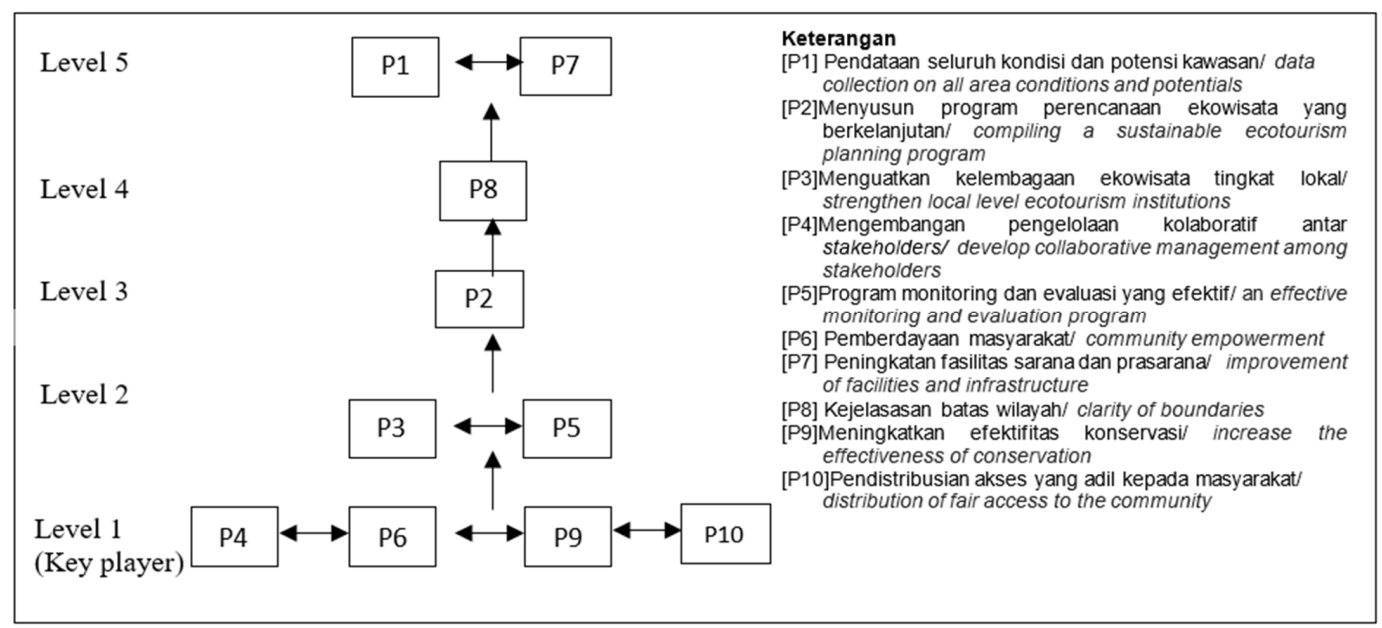

Gambar 5. Struktural Program Strategis (P) yang diperlukan dalam Pengelolaan Ekowisata Bahari di Kampung Wisata Distrik Meos Mansar Kabupaten Raja Ampat.

Figure 5. Structural of Strategy Program Management of Marine Ecotourism in Tourism Village, Meos Mansar District, Raja Ampat Regency.

Sumber: data primer (2020)/ Source: primary data (2020).

pemangku kepentingan perlu melakukan diskusi, negosiasi, perencanaan bersama, pengambilan keputusan bersama dan bertindak bersama di antara lembaga-lembaga untuk membentuk pengelolaan kolaborasi.

Pengelolaan kolaboratif (P4) perlu diterapkan khususnya untuk mengatasi permasalahan dalam sistem pengelolaan dan pemanfaatan tarif KJL yang menjadi tantangan terbesar untuk saat ini. Dalam sistem pengelolaan tarif KJL perlu mengembangkan pola manajemen kolaborasi dengan menyatukan kepentingan dan melakukan kerjasama antar pemerintah provinsi, pemerintah daerah, dinas pariwisata dan kebudayaan kabupaten, UPT BLUD, dinas perikanan, dinas perhubungan, BKSDA, dinas pekerjaan umum, masyarakat dan pihak terkait lainnya.

Pendistribusian pendapatan tarif KJL harus sesuai dengan kebijakan yang ada. Berdasarkan peraturan bupati, tarif KJL bagi wisatawan nusantara (wisnus) sebesar Rp500.000 dan bagi wisatawan mancanegara (wisman) sebesar Rp1.000.000. Dari tarif KJL wisnus dipotong Rp75.000 dan dari tarif KJL wisman dipotong Rp300.000 untuk dialokasikan ke Pendapatan Anggaran Daerah (PAD). Sisanya, Rp425.000 tarif KJL wisnus dan Rp700.000 tarif KJL wisman dikelola UPT BLUD untuk alokasikan ke biaya pembangunan kabupaten Raja Ampat, biaya operasional dan non operasional kawasan konservasi perairan, dan dana kesejahteraan masyarakat. Pelaporan jumlah wisatawan dan pendapatan tarif $\mathrm{KJL}$ harus dilaporkan secara jelas, berkala, dan mudah diakses oleh semua pihak untuk meningkatkan kepercayaan antar stakeholders dan keefektifan pengelolaan.

Program strategis pemberdayaan masyarakat (P6) dilakukan melalui peningkatan pelatihan dan pendampingan masyarakat. Beberapa pelatihan sudah diterima oleh sebagian masyarakat, namun belum diterima oleh seluruh masyarakat pelaku wisata. Masyarakat pelaku wisata membutuhkan pelatihan rutin dan pendampingan dalam upaya pengembangan ekowisata di kampung wisata. Pelatihan yang dibutuhkan seperti pelatihan standarisasi homestay, pelatihan pelayanan yang baik, pelatihan bahasa, pelatihan memasak, pelatihan pengelolaan keuangan homestay, pelatihan ketrampilan untuk membuat beragam produk oleh-oleh, dan pelatihan sertifikasi dive center dan tourguide. Selain dari sisi pelatihan dan pendampingan, perlu adanya dukungan kepada masyarakat lokal untuk memiliki fasilitas selam dan instruktur dive lokal sesuai standard international serta jaminan asuransi bagi penyelam untuk meningkatkan kepercayaan wisatawan dalam menggunakan fasilitas dan layanan kegiatan selam.

Program strategis peningkatkan efektivitas konservasi (P9) dilakukan dengan melibatkan berbagai stakeholders untukmengawasi penegakan aturan. Stakeholders yang dilibatkan dalam pengawasan meliputi masyarakat, UPT BLUD, satpol air, dinas kebudayaan dan pariwisata, dan 
Cl. Kegiatan pengawasan di beberapa titik pos penjagaan perairan kawasan konservasi berkurang pada saat pandemi Covid-19, dikarenakan adanya pengurangan petugas patroli UPT BLUD. Pengurangan petugas patroli UPT BLUD disebabkan oleh menurunnya pendapatan tarif $\mathrm{KJL}$ selama pandemi Covid-19. Berdasarkan informasi dari kepala UPT BLUD mengemukakan bahwa:

"Adanya pengurangan pekerja di UPT BLUD termasuk petugas patroli, dampaknya ditemukan kembali kegiatan merusak dari orang luar berupa illegal fishing. Pelaku usaha yang ikut patroli karena sering melintas di laut juga tidak ada karena tidak ada tamu. Namun setelah disuport oleh $\mathrm{Cl}$ dan satpol air, patroli dilakukan lagi meskipun petugas patroli di pos penjagaan tidak sebanyak sebelum pandemi"

Program strategis berupa pendistribusian akses yang adil kepada masyarakat (P10) harus memperhatikan keadilan prosedural, subtantif dan distributif. Keadilan akses menurut Schlosberg (2004) ditandai dengan tidak adanya ketimpangan dalam distribusi manfaat yang diterima setiap orang atau pihak tertentu di masyarakat. Berdasarkan definisinya, keadilan akses dapat mencakup pada tiga hal yaitu: (1) keadilan prosedural, yaitu keterlibatan seluruh pihak (masyarakat) dalam arti yang sebenarnya; (2) keadilan subtantif, yaitu hak untuk menikmati manfaat sesuai harapan; dan (3) keadilan distributif, yaitu penyebaran yang merata dari keuntungan yang diperoleh (Taylor, 2000). Keadilan prosedural dan subtantif telah dicapai oleh sebagian besar masyarakat kampung wisata karena mereka dilibatkan dalam perencanaan, pelaksanaan dan pengawasan pengelolaan ekowisata bahari dan memperoleh manfaat yang cukup sesuai dari adanya pengelolaan ekowisata bahari. Akan tetapi, keadilan distributif belum tercapai karena penyebaran manfaat belum dirasakan secara merata bagi seluruh masyarakat kampung wisata, seperti manfaat atau akses teknologi, modal, pasar, pengetahuan, dan kemitraan.

Program strategis pada Level 2 adalah menguatkan kelembagaan ekowisata di tingkat lokal (P3). Mayoritas masyarakat yang bekerja sebagai pelaku wisata bergabung kedalam asosiasi homestay Raja Ampat. Asosiasi homestay Raja Ampat dijadikan sebagai wadah pertukaran informasi para pelaku wisata dan kelompok pengembangan wisata.
Kelembagaan ekowisata di tingkat lokal perlu diperkuat kinerjanya dalam mengatur mekanisme pengelolaan sesuai prinsip keberlanjutan, mengorganisir kegiatan homestay dan pramuwisata, membangun pertukaran informasi antar anggota, dan mengembangan pariwisata berkelanjutan yang bekerja sama dengan berbagai stakeholders. Asosiasi homestay Raja Ampat berperan dalam membantu anggotanya memasarkan homestay melalui website. Pemilik homestay dipungut biaya perbulan untuk operasional website, akan tetapi aturan pungutan dinilai tidak adil. Dengan demikian, perlu menerapkan aturan pungutan yang diambil dari persenan berdasarkan pendapatan dari wisatawan yang masuk. Besaran persenan untuk biaya pungutan dapat ditentukan sesuai kesepakatan bersama. Selain itu, perlu dibentuk tim khusus pengurus Asosiasi Homestay Raja Ampat yang fokus mengurus administrasi dan mengembangkan usaha wisata di tingkat kabupaten.

Program strategis pada level 2 selanjutnya adalah program pengawasan dan evaluasi yang efektif (P5). Pengawasan kawasan konservasi telah dilakukan oleh tim patroli UPT BLUD dan satpol air. Namun, pelanggaran seperti lepas jangkar kapal yang tidak sesuai aturan, illegal fishing, buang sampah sembarang, dan kegiatan wisata fish feeding masih ditemukan. Selain itu, pengawasan dan evaluasi terhadap sistem pengelolaan dan pemanfaatan tarif KJL belum dilakukan secara efektif. Salah satu staff UPT BLUD mengemukakan bahwa "data wisatawan yang masuk dan yang bayar kadang suka tidak jelas datanya. Karena wisatawan ada yang bayar di pelabuhan, ada yang bayar di pos Arborek, bahkan ada juga yang tidak bayar karena wisatawan masuknya dari Sorong tidak melalui Waisai".

Ketidakjelasan pemasukan dari tarif $\mathrm{KJL}$ ini mempengaruhi besaran biaya operasional kawasan konservasi Raja Ampat dan distribusi pendapatan kepada masyarakat. Kejelasan pengaturan dan pemasukan tarif $\mathrm{KJL}$ dapat dilakukan dengan menerapkan sistem pengelolaan satu pintu, seperti membangun sistem pendaftaran dan pembayaran online bagi setiap wisatawan yang berkunjung. Wisatawan yang belum melakukan registrasi dan pembayaran, maka tidak bisa memasuki kawasan Raja Ampat. Sejalan dengan hal tersebut, maka perlu adanya pos penjagaan yang dapat mengecek status pendaftaran wisatawan. Program strategis pada Level $\mathbf{3}$ adalah menyusun program perencanaan ekowisata yang 
berkelanjutan (P2). Berdasarkan Rencana Induk Pengembangan Pariwisata Daerah (RIPPARDA) Kabupaten Raja Ampat, program perencanaan ekowisata mencakup: penetapan wilayah Destinasi Pariwisata Kabupaten (DPK) dan wilayah Kawasan Strategis Pariwisata Kabupaten (KSPK); (2) penetapan dan pengembangan daya tarik wisata, aksesibilitas, prasarana umum dan fasilitas umum, fasilitas pariwisata, pengembangan investasi; (3) pengembangan pemasaran pariwisata; (4) pengembangan industri pariwisata; (5) penguatan organisasi kepariwisataan; (6) pemberdayaan masyarakat melalui pariwisata. Hal penting yang perlu diperhatikan dalam penyusunan program perencanaan adalah melibatkan masyarakat, tokoh adat, tokoh agama, tokoh pemuda dalam setiap pengambilan keputusan.

Program strategis pada Level 4 adalah kejelasan batas wilayah (P8). Su, Wall, \& $\mathrm{Ma}$ (2014) mengemukakan bahwa masalah struktur pengelolaan tenurial dan ambiguitas lahan kepemilikan biasa terjadi di kawasan perlindungan. Demi memperjelas batas wilayah perlu pemasangan pelampung sebagai penanda batas. Program strategis pada Level 5 adalah pendataan seluruh kondisi dan potensi kawasan dan Peningkatan fasilitas sarana dan prasarana. Pendataan seluruh kondisi dan potensi kawasan (P1) masih menjadi tantangan dalam upaya pengembangan Kawasan Strategi Pariwisata Kabupaten (KSPK). Untuk melengkapi data kondisi dan potensi seluruh kawasan, perlu strategi bertahap dalam pengumpulan data. Pendataan dapat dimulai dengan melibatkan masyarakat lokal yang mengetahui kondisi dan potensi wilayahnya.

Program strategis lainnya pada level 5 adalah peningkatan fasilitas sarana dan prasarana (P7). Dalam upaya peningkatan fasilitas sarana dan prasarana di kampung wisata perlu dilakukan survei dan wawancara dengan masyarakat tentang kebutuhan sarana dan prasarana yang dibutuhkan. Identifikasi kebutuhan masyarakat dilakukan agar pembangunan fasilitas sarana dan prasarana tepat guna dan sesuai dengan kondisi lokal. Berdasarkan hasil wawancara dengan masyarakat, fasilitas sarana dan prasarana yang perlu dibangun dan ditingkatkan adalah jaringan listrik PLTD, drainase, pengelolaan limbah, dermaga semi permanen dengan kondisi yang baik, pelayanan kesehatan yang lengkap di kampung wisata, dan dive center sesuai standar international di tiap kampung wisata.
Pemetaan pemangku kepentingan menempatkan Pemerintah, Dewan Adat Suku Maya, dan Cl Indonesia termasuk kelompok key players yang memiliki kepentingan dan pengaruh tinggi. Pada kelompok context setter, terdapat lembaga penelitian atau akademisi seperti Universitas Cendrawasih dan Lembaga IImu Pengetahuan Indonesia (LIPI), yang memiliki kepentingan rendah namun tinggi pengaruhnya. $\mathrm{Di}$ lain pihak, masyarakat pelaku wisata, masyarakat non pelaku wisata, HPI Raja Ampat, dan asosiasi homestay Raja Ampat masuk ke dalam kelompok subjects, yang memiliki kepentingan tinggi namun rendah pengaruhnya. Posisi masyarakat masih menjadi subjek yang memiliki ketergantungan tinggi terhadap sumber daya tetapi pengaruhnya rendah terhadap pengambilan keputusan. Hasil memetaan ini secara umum menunjukkan bahwa masyarakat merupakan pihak yang paling perlu mendapatkan perhatian dalam penyempurnaan kelembagaan yang ada. Terkait hal itu, penguatan koordinasi dengan pihak otoritas (pemerintah) merupakan hal yang sangat relevan, misalnya melalui pengaktifan kembali Badan Pemusyawaratan Kampung (Bamuskam).

Hasil analisis lebih lanjut menunjukkan bahwa kelompok pemerintah, masyarakat, swasta, lembaga penelitian dan LSM perlu membentuk pengelolaan kolaborasi dalam rangka mengatasi berbagai kendala kelembagaan yang dihadapi dan melaksanakan program strategis pengelolaan ekowisata bahari di Kampung Wisata Raja Ampat. Kendala yang dihadapi dalam pengelolaan ekowisata Kampung Wisata Raja Ampat terdiri dari beberapa level. Kendala kelembagaan pada level pertama adalah konflik pemanfaatan ruang pada sistem pengelolaan dan pemanfaatan tarif Kartu Jasa Lingkungan (KJL). Kendala kelembagaan pada level pertama sangat menentukan penanganan kendala kelembagaan yang berada pada level selanjutnya.

Berdasarkan hasil identifikasi dan analisis kendala kelembagaan berikut adalah program strategis yang dapat dipertimbangkan untuk mengatasinya. Program strategis dimaksud terdiri dari beberapa level, namun perhatian dapat difokuskanpada program strategis pada level pertama; program strategis pertama ini akan menjadi pendorong elemen program strategis pada level selanjutnya. Program strategis pada level pertama tersebut meliputi: (1) pengembangan pengelolaan kolaboratif antar stakeholders; (2) pemberdayaan masyarakat; (3) meningkatkan 
efektivitas konservasi; dan (4) pendistribusian akses yang adil kepada masyarakat.

\section{IMPLIKASI KEBIJAKAN}

Program strategis yang perlu diprioritaskan adalah pengembangan pengelolaan kolaboratif antar stakeholders, pemberdayaan masyarakat, peningkatkan efektivitas konservasi, dan pendistribusian manfaat yang adil kepada masyarakat. Program startegis pertama, pengembangan pengelolaan kolaboratif antar stakeholders perlu diterapkan pada sistem pengelolaan dan pemanfaatan tarif KJL. Kendala kelembagaan pengelolaan tarif $\mathrm{KJL}$ muncul karenakan belum berlangsungnya pengelolaan secara terpadu antar stakeholders, menyangkut sistem, fungsi dan kebijakan. Pengelolaan tarif KJL perlu diatur melalui sistem pengelolaan satu pintu untuk menghindari tumpang tindih kebijakan terkait lembaga yang berwenang dalam mengelola tarif KJL. Wisatawan yang masuk ke kawasan wisata Raja Ampat perlu melakukan pendaftaran online ke halaman web yang dikelola oleh Dinas Pariwisata dan Kebudayaan Kabupaten Raja Ampat.

Dinas Pariwisata dan Kebudayaan Kabupaten Raja Ampat perlu koordinasi dengan Pemerintah Daerah Kabupaten Raja Ampat dan Badan Pengelolaan Keuangan dan Aset Daerah (BPKAD) Kabupaten Raja Ampat terkait pendaftaran dan pembayaran tarif masuk wisata yang dibayarkan oleh wisatawan. Pendaftaran dan pembayaran tarif masuk wisata atau tarif KJL seyogyanya dilakukan dengan sistem online, agar pelaporannya jelas, terukur dan mudah diakses. Pemerintah daerah bersama BPKAD harus memastikan pendapatan tarif masuk wisata dialokasikan untuk pembangunan infrastruktur kebutuhan wisata, pemberdayaan masyarakat sebagai pelaku wisata dan pembiayaan operasional maupun non operasional Kawasan Konservasi Perairan Raja Ampat. Harus ada penekanan bahwa ekowisata bahari di Raja Ampat diarahkan pada sifat mutualisme konservasi; terkait hal ini, Dinas Pariwisata dan Kebudayaan Raja Ampat perlu melakukan koordinasi pengelolaan dengan Unit Pelaksana Teknis Badan Layanan Umum Daerah (UPT BLUD) dan Balai Konservasi Sumber Daya Alam (BKSDA). UPT BLUD berada di bawah kewenangan Dinas Kelautan dan Perikanan Provinsi Papua Barat. Kementerian Kelautan dan Perikanan perlu mendukung dan memastikan sistem pengelolaan dan pemanfaatan tarif masuk wisata dikelola dengan baik untuk keberlanjutan Kawasan Konservasi Perairan Kabupaten Raja Ampat.

Program strategis kedua adalah perlunya peningkatan pelatihan dan pendampingan pelaku wisata oleh Dinas Pariwisata dan Kebudayaan Kabupaten Raja Ampat serta Dinas Koperasi dan UKM Kabupaten Raja Ampat. Program strategis ketiga adalah meningkatkan efektivitas konservasi dengan melibatkan berbagai stakeholders sebagai pengawas untuk memastikan aturan yang dibuat telah dipatuhi. Stakeholders yang dapat dilibatkan dalam pengawasan meliputi masyarakat, UPT BLUD, Satpol Air, Dinas Kebudayaan dan Pariwisata Kabupaten Raja Ampat, dan Conservation Internasional Indonesia. Program strategis keempat adalah menjamin pendistribusian akses yang adil kepada masyarakat harus memperhatikan keadilan prosedural, subtantif dan distributif.

\section{UCAPAN TERIMA KASIH}

Ucapan terima kasih peneliti sampaikan kepada Kementerian Riset, Teknologi, dan Pendidikan Tinggi Republik Indonesia, skema penelitian program magister menuju doktor untuk sarjana unggulan yang telah mendanai penelitian sesuai kontrak penelitian tahun anggaran 2019 Nomor: 3/E1/KP.PTNBH/2019. Kami mengucapkan terima kasih kepada Dinas Pariwisata dan Kebudayaan Kabupaten Raja Ampat, Unit Pelaksana Teknis Badan Layanan Umum Daerah, Badan Perencanaan dan Pembangunan Daerah Kabupaten Raja Ampat, Conservation International Indonesia, Asosiasi Homestay Raja Ampat, Kepala Kampung Wisata Arborek, Yenbuba dan Sawinggrai yang telah banyak membantu peneliti dalam mengumpulkan data.

\section{PERNYATAAN KONTRIBUSI PENULIS}

Nuraini sebagai kontributor utama dan Arif Satria, Ekawati Sri Wahyuni, dan Dietrich Geoffrey Bengen sebagai kontributor anggota. Nuraini berkontribusi dalam membangun kerangka pemikiran, melakukan pengambilan data di lapang, mengumpulkan data primer dan sekunder, menganalisis data, dan menulis artikel. Arif Satria berkontribusi dalam memberi saran kerangka teoritis, membuat judul artikel dan memberi ulasan pada artikel. Ekawati Sri Wahyuni dan Dietrich Geoffrey Bengen berkontribusi dalam merancang metode penelitian dan memberi ulasan pada artikel. 


\section{DAFTAR PUSTAKA}

[Bappeda] Badan Perencanaan Pembangunan Daerah Kabupaten Raja Ampat. (2010). Raja Ampat: buku rencana tata ruang wilayah Kabupaten Raja Ampat 2010 - 2030.

Brinkerhoff, D.W., \& Goldsmith, A.A. (1992). Promoting the sustainability of development institutions: a framework for strategy. World development, 20(3), 369-383. doi:10.1016/0305-750X(92)90030-Y.

Brown, H.C.P. (2018). An Assessment of institutional capacity for integrated landscape management in Eastern Cameroon. Environmental Management, 62(1), 118-127. doi: 10.1007/ s00267-018-1048-z.

Bryson, J.M. (2004). What to do when stakeholders matter: stakeholders identification and analysis techniques. Public management review, 6(1), 21-53. doi: 10.1080/14719030410001675722.

Creswell, J.W. (2014). Research Design, Qualitative, Quantitative, and Mixed Methods Approaches, Fourth Edition. Los Angeles, US: SAGE Publication.

Damanik, J., \& Weber, H.F. (2006). Perencanaan Ekowisata: dari Teori ke Aplikasi. Yogyakarta, ID: Penerbit Andi.

Dinas Pariwisata dan Kebudayaan Kabupaten Raja Ampat. (2017). Pendapatan Penjualan Kartu Jasa Lingkungan Tahun 2016 Kabupaten Raja Ampat.

Fidelman, P., Evans, L., Fabinyi, M., Foale, S., Cinner, J., \& Rosen, F. (2012). Governing large-scale marine commons: contextual challenge in the coral triangle. Marine Policy, 36(1), 42-53. doi: 10.1016/j.marpol.2011.03.007.

Hero, Y. (2012). Peran Kelembagaan dalam Proses Pemebuatan Kebijakan Pengelolaan Hutan Pendidikan Gunung Walat Berdasarkan Pendekatan Diskursus dan Sejarah [disertasi]. Bogor, ID: IPB University.

Hiwasaki, L. (2007). Community dynamics in Japanese rural areas and implications for national park management. International Journal of Biodiversity Science and Management, 3 (2), 102-114. doi: 10.1080/17451590709618166.

Honrado, J.P., Lomba, A., Alves, P., Aguiar, C., MonteiroHenriques, T., Cerqueira, Y., Monteiro, P., \& Caldas, F.B. (2017). Conservation management of EU priority habitats after collapse of traditional pastoralism: navigating socioecological transitions in Mountain Rangeland. Rural Sociology, 82 (1), 101-128. doi: 10.1111/ ruso. 12111 .

Hukom, F.D., Yulianda, F., Bengen, D.G., \& Kamal, M.M. (2019). Efektivitas Zonasi dalam Pengelolaan Perikanan Karang di Kawasan Konservasi
Perairan Selat Dampier, Raja Ampat. Jurnal Kebijakan Sosial Ekonomi Kelautan dan Perikanan, 9 (2), 93-103. doi: 10.15578/jksekp. v9i2.7661.

Jayant, A., \& Azhar, M. (2014). Analysis of the barriers for implementing green supplay chain management (GSCM) practices: an interpretive structural modeling (ISM) approach. Procedia Engineering, 97, 2157-2166. doi: 10.1016/j. proeng.2014.12.459.

Kanungo, S., \& Bhatnagar, V.V. (2002). Beyond generic models for information system quality: the use of interpretive structural modeling (ISM). Systems Research and Behavioral Science, 19(6), 531-549. doi: 10.1002/sres.476.

Kanyuuru, C.K., Mburu, J., \& Njoka, J. (2017). Adaptation of institutional arrangements to management of Northern Rangelands of Kenya. Environment, Development and Sustainability, 19(1), 67-82. doi: 10.1007/s10668-015-9718-y.

Mohammed, I.R., Shankar, R., \& Banwet, D.K. (2008). Creating flex-lean-agile value chain by outsourcing: an ISM-based interventional roadmap. Business Process Management Journal, 14,338-339. doi: 10.1108/14637150810876670.

Muttaqin, M.Z. (2012). Designing payments for environmental services (PES) to reduce emissions from deforestation and forest degradation (REDD+) in Indonesia [disertasi]. Australia, AU: The Australian National University.

Nurfatriani, F., Darusman, D., Nurrochmat, D.R., \& Yustika, A.E. (2015). Analisis pemangku kepentingan dalam trlnnovation Agenansformasi kebijakan fiskal hijau. Forestry Research, Development and Innovation Agency.

Ostrom, E. (1990). Governing The Commons. New York, US: Cambridge Univ Press.

Peraturan Bupati Kabupaten Raja Ampat Nomor 63 Tahun 2007 tentang Retribusi ljin Masuk Wisata di Kabupaten Raja Ampat.

Peraturan Bupati Kabupaten Raja Ampat Nomor 64 Tahun 2007 tentang Pengelolaan Dana Pengembangan Kepariwisataan Non-Retribusi Bagi Masyarakat Kabupaten Raja Ampat.

Peraturan Bupati Kabupaten Raja Ampat Nomor 65 Tahun 2007 tentang Pembentukan Tim Pengelola Dana Pengembangan Kepariwisataan Non-Retribusi Bagi Masyarakat Kabupaten Raja Ampat.

Peraturan Bupati Kabupaten Raja Ampat Nomor 18 Nomor 2014 Tentang Tarif Layanan Pemeliharaan Jasa Lingkungan pada Badan Layanan.

Reed, M.S, Graves, A., Dandy, N., Posthumus, H., Hubacek, K., Morris, J., Prell, C., Quinn, C.H., \& Stringer, L.C. (2009). Who's in and why? A typology of stakeholder analysis methods 
for natural resource management. Journal of Enviromental Management, 90(5), 1933-1949. doi: 10.1016/j.jenvman.2009.01.001.

Rencana Induk Pengembangan Pariwisata Daerah (RIPPARDA) Kabupaten Raja Ampat Tahun 2014-2034.

Rudyanto, Rumetna, L., Setyawan, D., Prabowo, N.A. (2015). Laporan akhir dokumentasi proses dan pembentukkan KKPD Raja Ampat dan Pembentukan BLUD UPTD KKPD Raja Ampat. The Nature Conservancy Indonesia.

Satria, Arif. (2002). Pengantar Sosiologi Masyarakat Pesisir. Jakarta, ID: PT Pustaka Cidesindo.

Satria, Arif. (2009). Pesisir dan Laut untuk Rakyat. Bogor, ID: IPB Press.

Saxena, J.P., \& Vrat, P. (1992). Scenario building: a critical study of energy conservation in the Indian cemen industry. Technological Forecasting and Social Change, 41(2), 121-146. doi: 10.1016/00401625(92)90059-3.

Schlosberg, D. (2004). Reconceiving environmental justice: global movements and political theories. Environmental politics, 13 (3), 517 -540. doi: 10.1080/0964401042000229025.

Su, M.M., Wall, G., \& Ma, Z. (2014). Assessing ecotourism from a multi-stakeholder perspective: Xingkai lake national nature reserve, China. Environmental Management, 54(5), 1190-1207. doi: 10.1007/ s00267-014-0360-5.

Taylor, D.E. (2000). The rise of the environmental justice paradigm: Injustice framing and the social construction of environmental discourse. American Behavioral Scientist, 43 (4), 508-580. doi: 10.1177/0002764200043004003.

Thia-Eng, C. (2006). The Dynamics of Integrated Coastal Management: Practical Applications in the Sustainable Coastal Development in East Asia. Quenzon, PH: PEMSEA.

Triyanti, R., \& Susilowati, I. (2019). Analisis Pemangku Kepentingan dalam Pengelolaan Kawasan Pesisir Berkelanjutan di Kabupaten Gunungkidul. J. Kebijakan Sosial Ekonomi Kelautan dan Perikanan, 9 (1), 23-34. doi: 10.15578/jksekp.v9i1.7324.

Undang-Undang Republik Indonesia Nomor 27 Tahun 2007 tentang Pengelolaan Kawasan Pesisir dan Pulau-pulau Kecil.

Undang-Undang Republik Indonesia Nomor 10 Tahun 2009 tentang Kepariwisataan.

Wood, E.M. (2002). Ecotourism: principles, practices \& policies for sustainability. Paris, FR: UNEP publication.
Yeboah-Assiamah, E., Muller, K., \& Domfeh, K.A. (2016). Rising to the challenge: A framework for optimising value in collaborative natural resource governance. Forest Policy and Economics, 67, 20-29. doi: 10.1016/j.forpol.2016.01.008. 